\title{
Optimal control of a high gain DC- DC converter
}

\author{
Lopamudra Mitra ${ }^{1}$, Ullash Kumar Rout ${ }^{2}$ \\ ${ }^{1}$ Department of Electrical and Electronics Engineering, Silicon Institute of Technology, Bhubaneswar, India \\ ${ }^{2}$ Department of Electrical Engineering, College of Engineering and Technology (CET), Bhubaneswar, India
}

\begin{tabular}{l} 
Article Info \\
Article history: \\
Received Nov 12, 2020 \\
Revised Jan 24, 2022 \\
Accepted Jan 31, 2022 \\
\hline Keywords: \\
Bacteria foraging algorithm \\
High gain DC-DC converter \\
Particle swarm optimisation \\
Photovoltaic systems \\
PID controller
\end{tabular}

PID controller

\begin{abstract}
Different types of power conditioning systems are mostly used with renewable energy systems. As the output of solar photovoltaic (PV) is low high voltage converters are required. These converters can be used for both standalone and grid tied systems. A high voltage gain DC-DC converter is proposed which can be used with photovoltaic modules to get high output voltage. This converter can provide a high voltage gain and a proportional integral derivative (PID) controller is used to maintain the high output voltage of the proposed converter coupled with solar photovoltaic module. The PID controller is first designed using classical Ziegler Nichol's method $(\mathrm{ZN})$ and optimal control of the converter is obtained by using different optimisation methods like particle swarm optimisation (PSO), bacteria foraging algorithm (BFA) and its comparison is presented in this paper.
\end{abstract}

This is an open access article under the CC BY-SA license.

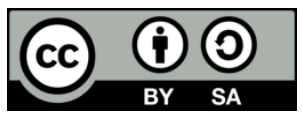

\section{Corresponding Author:}

Lopamudra Mitra

Department of Electrical and Electronics Engineering, Silicon Institute of Technology

Bhubaneswar, India

Email: lopamudra.mitra2015@gmail.com

\section{INTRODUCTION}

As there is fast depletion of fossil fuels owing to its higher cost, renewable energy systems have to be deployed to meet the power demand. But these renewable energy sources have to be integrated to the power system network. For integration of these renewable energy systems power conditioning systems like DC-DC converters or inverters are used. Renewable energy systems can be standalone type or grid tied type. The high voltage, high power converters are required as the efficiency and the output of the solar photovoltaic (PV) systems is low, hence high gain converters with higher power and efficiency are required. There are different topologies of high gain DC-DC converters, both single stage and multi-stage are found in literature. All these converters have both the advantages and limitations.

Mostly the high gain DC boost are used which are either non-isolated type or isolated type with transformer. The topologies with isolation transformers suffer from lower efficiency and higher cost, weight and volume in comparison to non-isolated type [1]. A switched capacitor topology of boost converter is used to get high output voltage gain and efficiency, component count is high and has higher value of input ripple current [2]. Other hybrid topologies found in literature with combination of switched capacitor and inductor have low voltage stress on diodes and switches, also has low ripple current. But the main drawback is that high output voltage cannot be gained [3], [4]. Other topologies found in literature have transformers for isolation and high voltage stress on switches. The major drawback of high frequency transformer is the loss due to parasitic capacitance. Also, the leakage inductance of the transformer leads to increase in voltage spikes ultimately increase in operating volage, due to the switching operation of the converter. Undesired volage regulation occurs due to drop across the leakage reactance with change in load. As for high voltage applications, magnetic materials size cannot be reduced as I will require high insulation [5]-[19]. So, a new non-isolated or transformer, high gain DC-DC converter is proposed as a solution. 


\section{PROPOSED CONVERTER}

As shown in Figure 1 the proposed converter is composed of metal oxide semiconductor field effect transistor (MOSFET) switch $\mathrm{S} 1$, inductor $\mathrm{Lm}$, resonant capacitor $\mathrm{Cr}$, clamping capacitor $\mathrm{Cc}$, resonant inductor Lr, and diodes Do, $\mathrm{D}_{1}$ and Dr. Ro is the resistive load [20]-[23]. In this converter all the switches, diodes are assumed to be ideal and a constant voltage source is considered. The modes of operation of this converter are given as:

- Mode-I: At first the switch S1 is turned on and the inductor is energised from the input voltage and the clamping capacitor charges the resonant capacitor $\mathrm{Cr}$. The charged capacitor transfers energy to the load when switch is off. The inductor current with resonant current provides the switch current.

- Mode-II: In this mode the switch is turned off and the leakage energy stored in the inductor in the previous mode charges the clamping diode D1 and in turn Cc gets charged causing clamping of voltage of the switch S1.

- Mode-III: After mode-II, the output diode Do is forward biased as the capacitor Cc got charged and the energy stored in Lm and $\mathrm{Cc}$ is transferred to the load and diode D1 continues to conduct till Cc gets discharged.

- Mode-IV: In this mode, D1 gets reverse biased and during steady state operation the capacitor $\mathrm{Cr}$ is charged to maintain the balance.

- Mode-V: During this mode, the output diode gets reverse biased when the switch S1 is turned on again and the next switching cycle begins. Figure 2 to Figure 6 shows all the modes of operation.

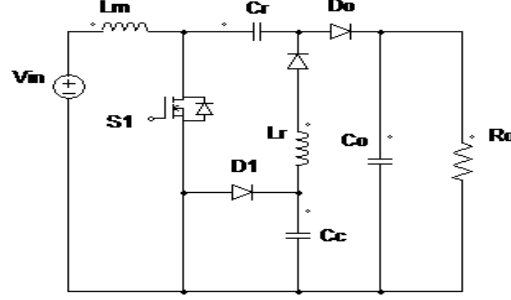

Figure 1. The proposed converter

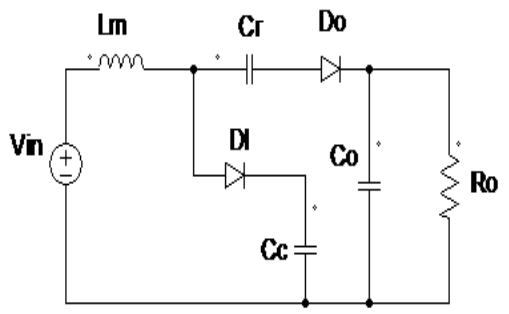

Figure 4. Mode-III

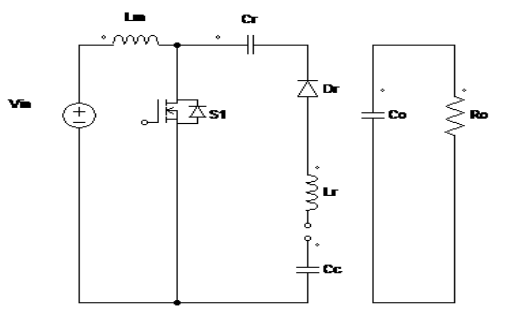

Figure 2. Mode-I

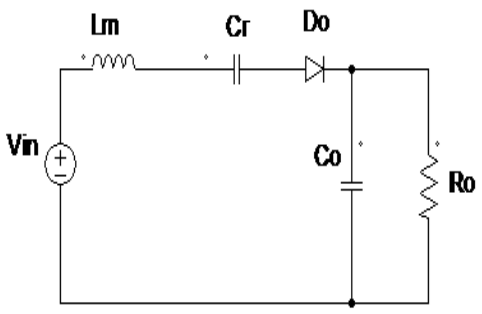

Figure 5. Mode-IV

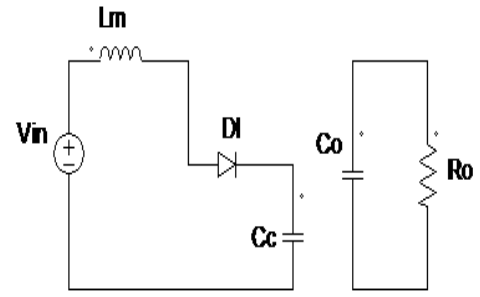

Figure 3. Mode-II

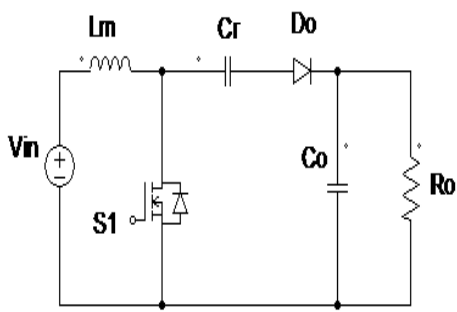

Figure 6. Mode-V

\section{CLOSED LOOP CONTROL OF THE PROPOSED CONVERTER}

As solar PV system is an intermittent source, the output changes with the pv a controller is required to maintain a constant output. The proposed converter is coupled with PV module to give high output voltage. For closed loop control of a system proportional integral (PI) proportional derivative (PD), proportional integral derivative (PID), proportional derivative (PDD). Are used and to reduce the steady state error. PID controllers are mostly used to control non- linear systems. Three basic modes like proportional, integral and derivative mode are used in this controller. For higher order system the proportional controller cannot be used as basically they are used o stabilize first order systems. Forced oscillations cannot be controlled P and on-off controller as compared to PI controller. But the response of PI controller becomes sluggish when integral mode is included. PI controllers can be used for processes where faster response is not required. Prediction of error is not possible in his controller. But by including a derivative mode future prediction of error can be obtained and it also provides a faster response. Hence PID controller can be used in non-linear systems like solar PV and it gives a faster response to any change in the input (D). There is also reduction in error to almost zero (I). So PID controller has all the necessary characteristics required, hence used in his work for closed loop control of the converter. 
The output of the controller is given as:

$\mathrm{U}(\mathrm{t})=\mathrm{Kpe}(\mathrm{t})+\mathrm{Ki} \int \mathrm{e}(\mathrm{t}) \mathrm{dt}+\mathrm{Kd} \frac{d e(t)}{d t}$

where,

e(t) : Input error signal

$\mathrm{U}(\mathrm{t}) \quad$ : Output signal

\subsection{Design of PID controller using Ziegler Nichol's method}

State averaging technique: In order to obtain the steady state and dynamic responses of the complete model of the converter. This technique is an important tool to design a power converter. By using his technique a relationship between the sources, outputs and control parameters can be obtained. Large scale changes in voltages and currents as the source, load or control inputs can be tracked by the averaged model and also complicated models can be easily obtained. In this method $\tilde{v}_{o}$ and $\tilde{d}_{s}$ are small perturbations in the output voltage $v_{o}$ and the switch duty ratio d; a small signal transfer function is given as $\tilde{v}_{o} / \tilde{d}_{s}$. At first for the switching states the sae variables are obtained. The inductor current and capacitor voltage are described as state variable vector $\mathrm{x}$. The small ac perturbation added to the $\mathrm{DC}$ value given as $v_{o=} V_{o}+\tilde{v}_{o}$. The state equations during switch $\mathrm{ON}$ and $\mathrm{OFF}$ time are given as:

$$
\begin{aligned}
& \dot{x}=A_{1} x+B_{1} v_{d} \\
& \dot{x}=A_{2} x+B_{2} v_{d}
\end{aligned}
$$

where $\mathrm{A}_{1}$ and $\mathrm{A}_{2}$ are state matrices, $\mathrm{B}_{1}$ and $\mathrm{B}_{2}$ are vectors, $v_{d}$ is the input voltage.

Also during the switching states the output voltage can be described in terms of state variables is given as:

$$
\begin{aligned}
& v_{o}=C_{1} x \\
& v_{o}=C_{2} x
\end{aligned}
$$

where $C_{1}$ and $C_{2}$ are transposed vectors.

The averaged model is given by the following equations over total switching period as:

$$
\begin{aligned}
& \dot{x}=\left[A_{1} d+A_{2}(1-d)\right] x+\left[B_{1} d+B_{2}(1-d)\right] v_{d} \\
& v_{o}=\left[C_{1} d+C_{2}(1-d)\right] x
\end{aligned}
$$

Finally the transfer function $\mathrm{T}_{\mathrm{p}}(\mathrm{s})$ of the converter can be obtained in this form,

$$
T_{P}(s)=\frac{\tilde{v}_{o}(s)}{\tilde{d}(s)}=C[s I-A]^{-1}\left[\left(A_{1}-A_{2}\right) X+\left(B_{1}-B_{2}\right) V_{d}\right]+\left(C_{1}-C_{2}\right) X
$$

By using the state space averaging (SSA) technique the averaged matrices are obtained as:

$$
\begin{aligned}
& A=A 1 \times d+A 2 \times(1-d) \\
& B=B 1 \times d+B 2 \times(1-d) \\
& C=C 1 \times d+C 2 \times(1-d) \\
& D=D 1 \times d+D 2 \times(1-d)
\end{aligned}
$$

The control transfer function is defined as the ratio of output voltage to duty ratio and it is obtained as (8).

$$
\frac{V o(s)}{d(s)}=C \times(S I-A)^{-1}(A 1-A 2) X
$$

Where

$$
X=-A^{-1} \times B \times V_{\text {in }}
$$


After state space averaging technique and state space analysis of the model and using MATLAB program/.m file, the root locus plot of the converter is obtained as shown in Figure 7 and from the root locus plot critical gain $\mathrm{K}_{\mathrm{c}}$ and critical time period $\mathrm{T}_{\mathrm{c}}$ was obtained [23]. To tune the parameters of the controller Ziegler Nichols method is used. The Ziegler Nichols tuning method is a heuristic method of tuning a PID controller [2]. To meet the performance requirements the controller parameters are tuned with the rules suggested by Ziegler and Nichols as shown in Table 1 [24].

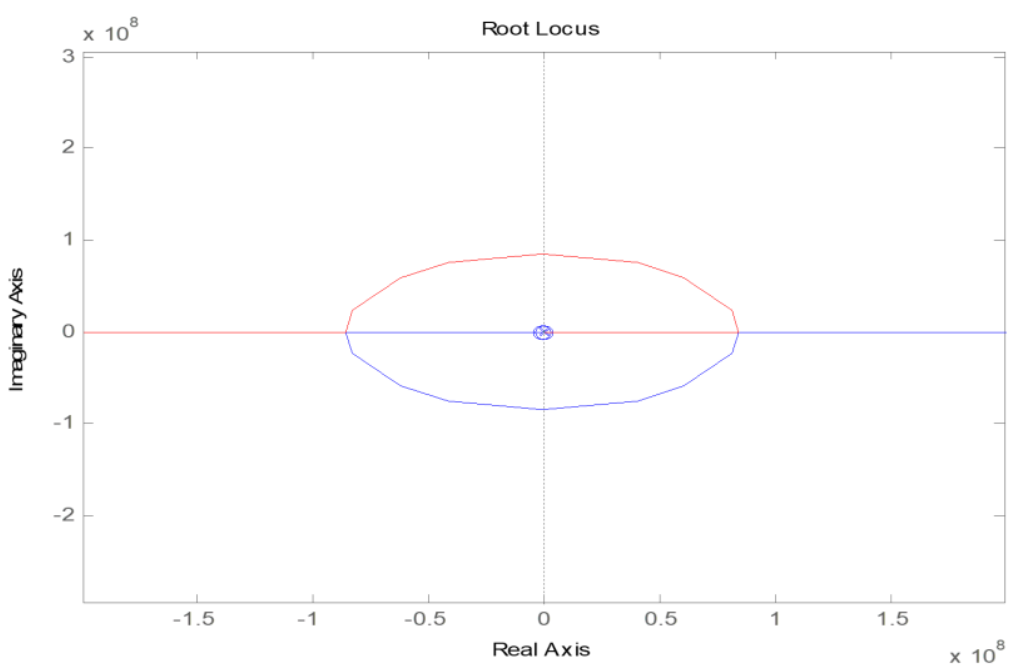

Figure 7. Root locus plot of the proposed converter without controller

Table 1. Ziegler nichol's method of tuning

\begin{tabular}{cccc}
\hline Type of controller & $\mathrm{Kp}$ & $\mathrm{Ti}$ & $\mathrm{Td}$ \\
\hline P & $0.5 \mathrm{Kc}$ & $\infty$ & 0 \\
PI & $0.45 \mathrm{Kc}$ & $0.82 \mathrm{Tc}$ & 0 \\
PID & $0.6 \mathrm{Kc}$ & $0.5 \mathrm{Tc}$ & $0.125 \mathrm{Tc}$ \\
\hline
\end{tabular}

The critical gain was found to be $\mathrm{K}_{\mathrm{c}}=8.18 \times 10^{7}$. Here in the proposed converter, we will use PID controller. So, the parameters are:

$$
\begin{aligned}
& K_{p}=0.6 K_{c} \\
& T_{i}=0.5 T_{c} \\
& \Rightarrow T_{i}=0.3685 \times 10^{-7} \text { Seconds } \\
& T_{d}=0.125 T_{c} \\
& \Rightarrow T_{d}=0.0921 \times 10^{-7} \text { Seconds } \\
& K_{i}=\frac{K_{p}}{T_{i}}, K_{d}=K_{p} T_{d}
\end{aligned}
$$

In this work PID controller is used to keep the output voltage constant, PID controller is used in this work. The simulation diagram of the proposed converter with PID controller is shown in Figure 8 whose parameters are tuned using Ziegler Nichols method. The output voltage of the high gain converter is $300 \mathrm{~V}$ for input voltage of $30 \mathrm{~V}$ without controller is shown in Figure 9. Now with the use of PID controller; a constant voltage of $300 \mathrm{~V}$ is to be maintained for different input voltages. The simulation result is shown in Figure 10. The Figure 10 shows output voltage of the converter is $299.2 \mathrm{~V}$ for input voltage of $30 \mathrm{~V}$ with PID controller. When the proposed converter is coupled with the PV module as shown in Figure 11, the output voltage of the converter changes as the PV output voltage change with the irradiance, hence PID controller is used to keep the output voltage constant at 300V. The simulation results are shown in Figures 12 and 13. Table 2 shows the output voltage of the converter with changing irradiance with PID controller designed by Ziegler Nichol's method. 


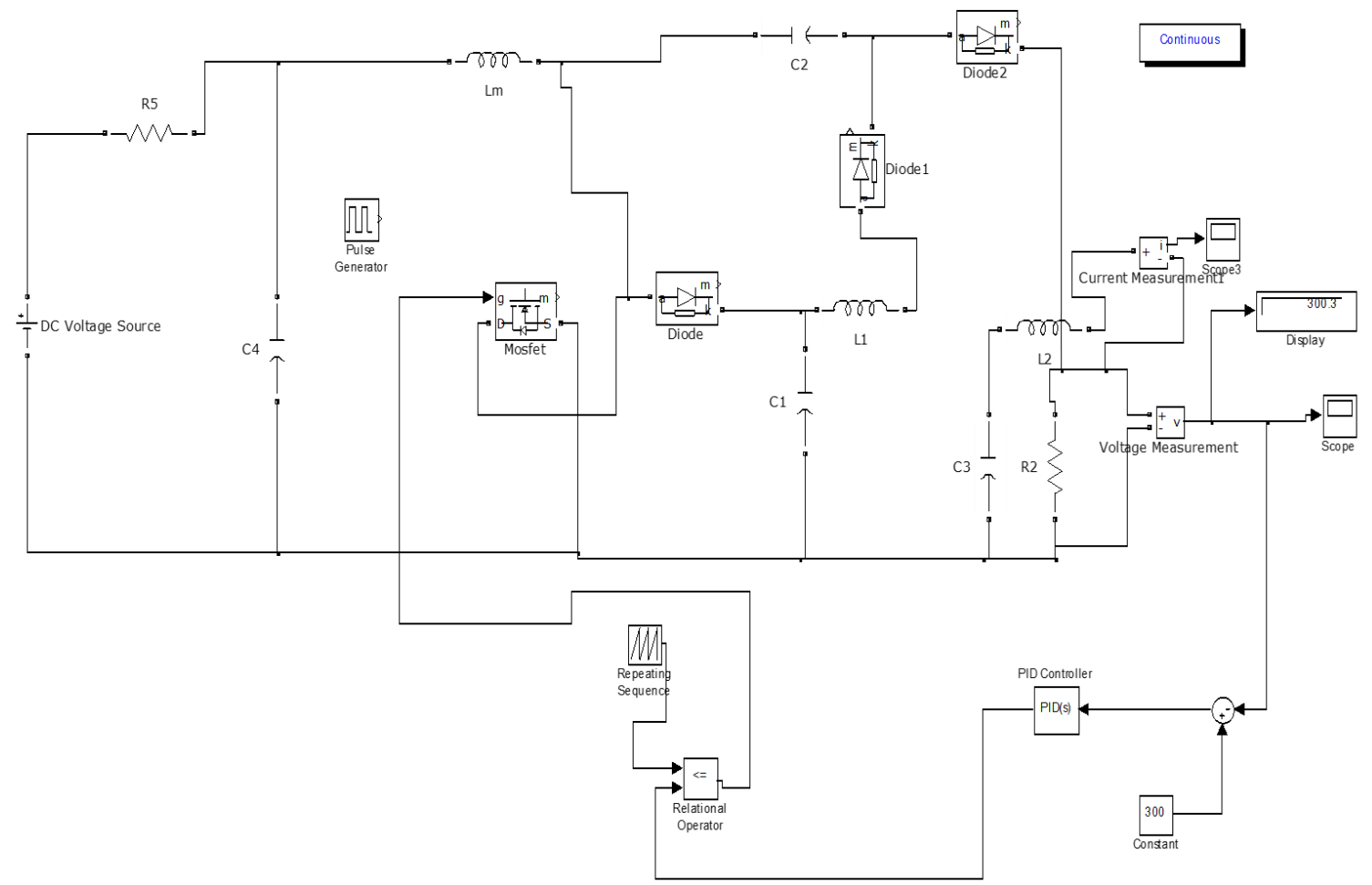

Figure 8. Simulation diagram of the proposed DC-DC converter with PID controller

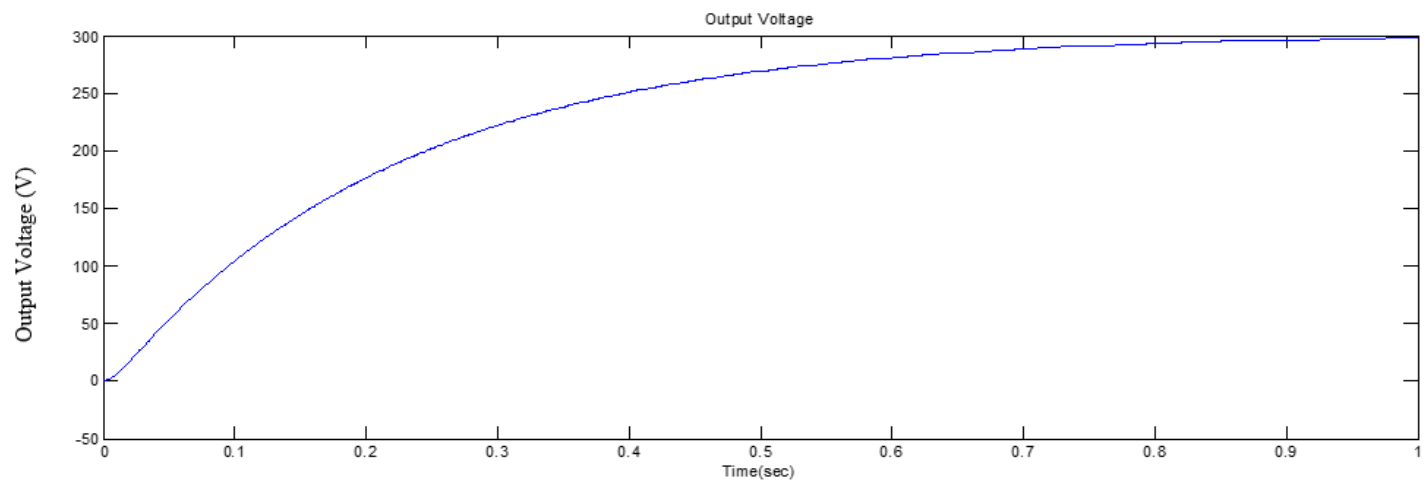

Figure 9. Output voltage of the high gain converter is $300 \mathrm{~V}$ for input voltage of $30 \mathrm{~V}$ without controller

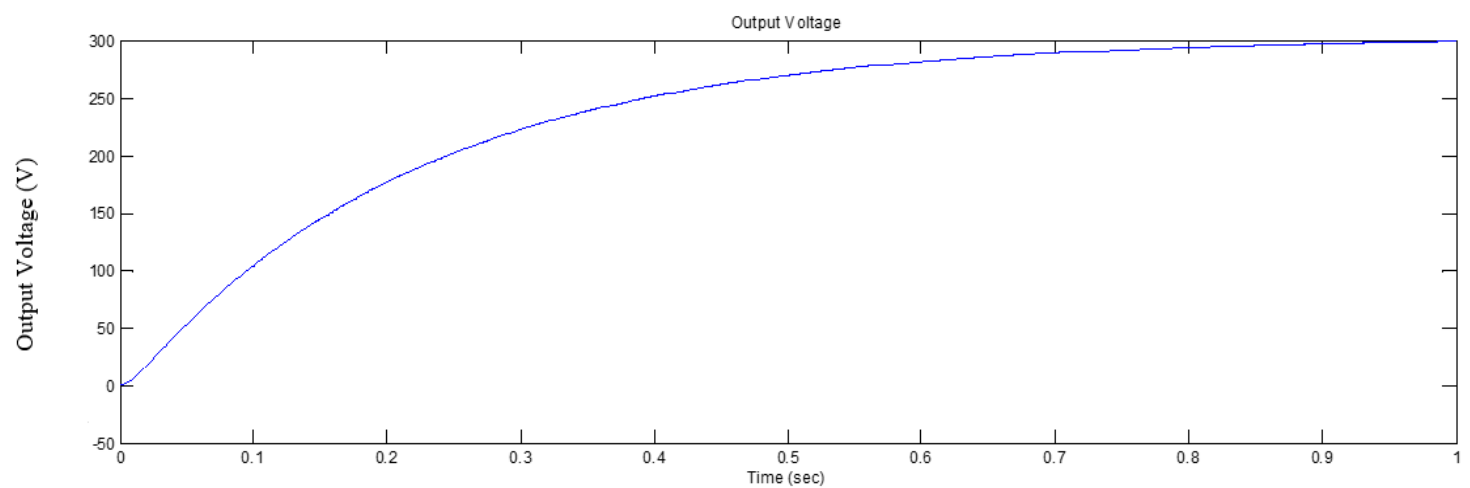

Figure 10. Output voltage of the converter is $299.2 \mathrm{~V}$ for input voltage of $30 \mathrm{~V}$ with controller 


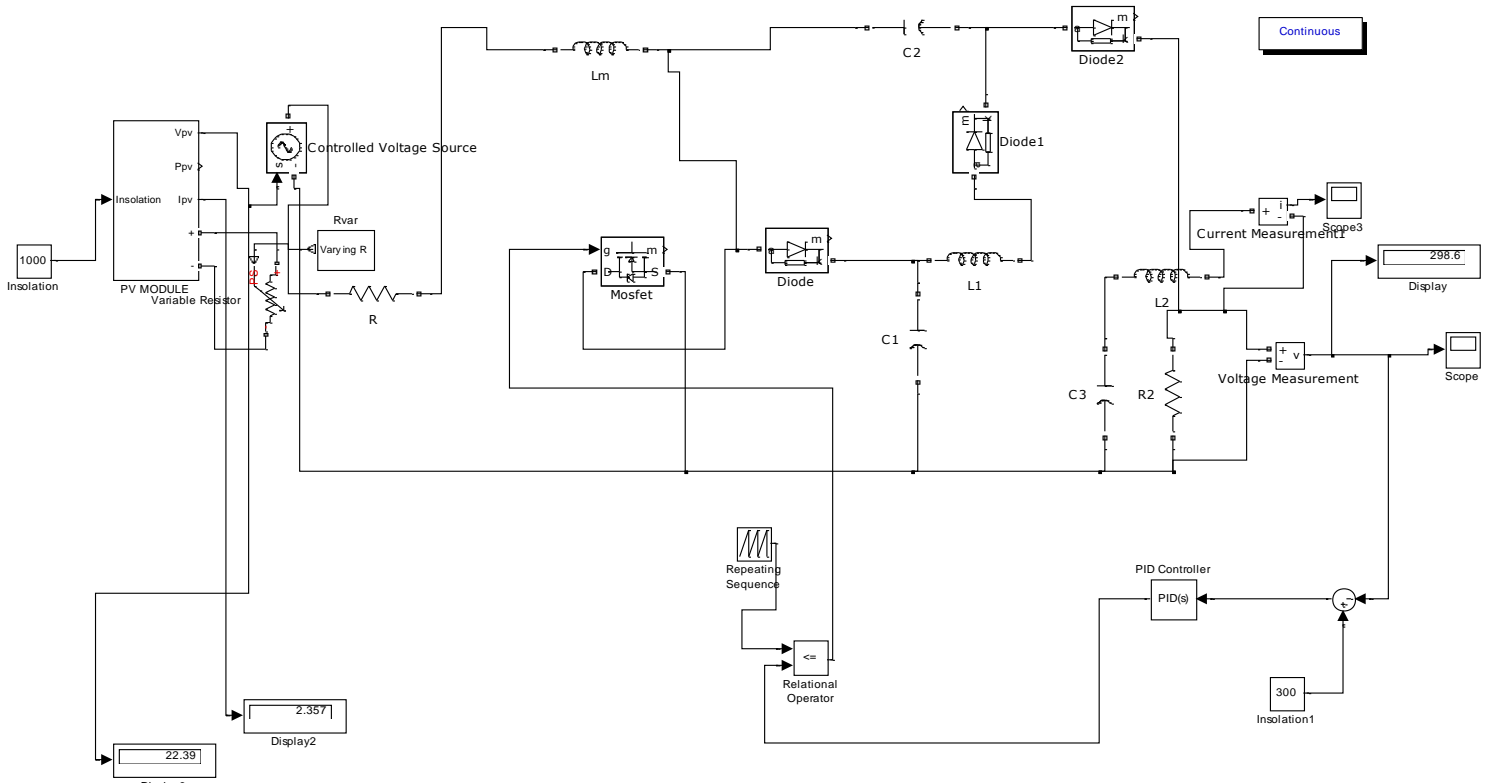

Figure 11. Simulation diagram of the proposed DC-DC converter with PID controller coupled with PV module

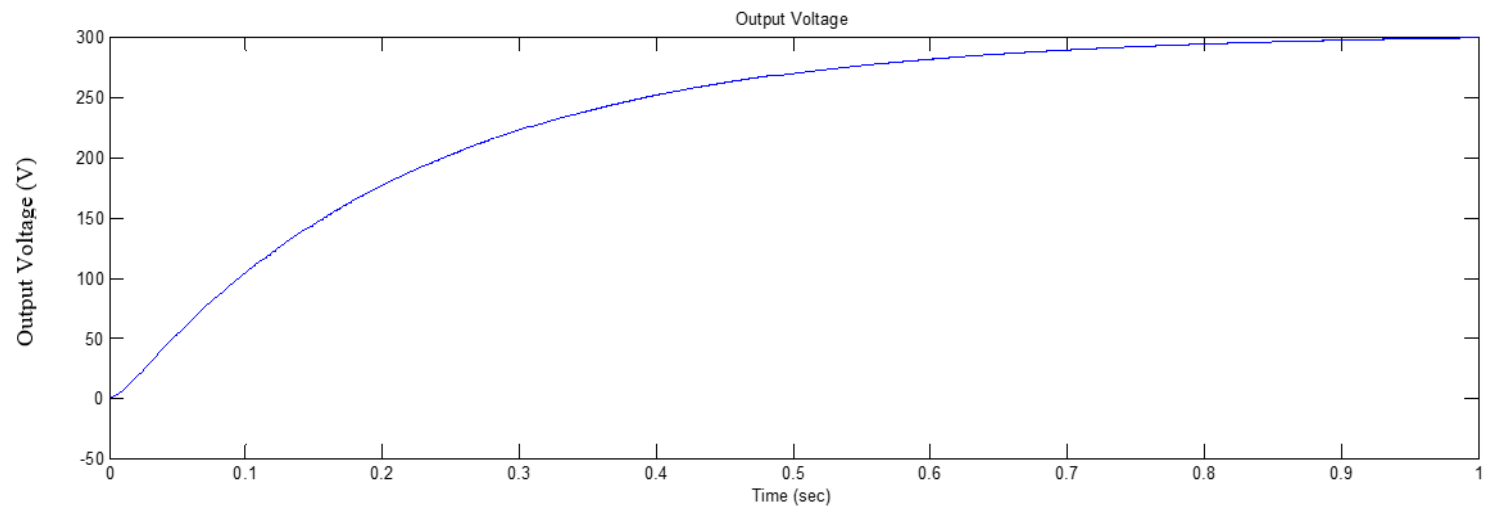

Figure 12. Output voltage of the converter is $299.2 \mathrm{~V}$ with input voltage of $36.7 \mathrm{~V}$ from PV module with irradiance $1000 \mathrm{~W} / \mathrm{m}^{2}$

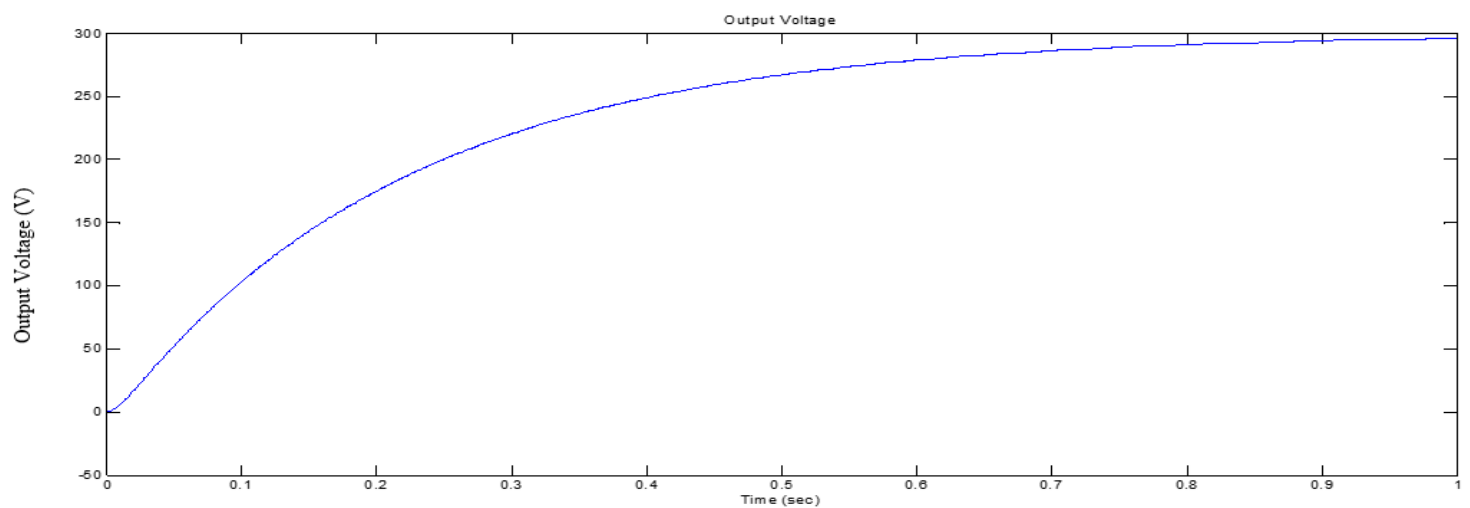

Figure 13. Output voltage of the Converter is $296.1 \mathrm{~V}$ with input voltage of $18.04 \mathrm{~V}$ from PV module with irradiance $400 \mathrm{~W} / \mathrm{m}^{2}$ 
Table 2. Output voltage of the converter with changing irradiance with pid controller designed by Ziegler Nichol's method

\begin{tabular}{cccccccc}
\hline $\begin{array}{c}\text { Irradiance } \\
\text { in W/m }\end{array}$ & $\begin{array}{c}\text { Input Voltage } \\
\left(\mathrm{V}_{\text {in }}\right)\end{array}$ & $\begin{array}{c}\text { Input Current } \\
\left(\mathrm{I}_{\text {in }}\right)\end{array}$ & $\begin{array}{c}\text { Input Power } \\
\left(\mathrm{P}_{\text {in }}\right)\end{array}$ & $\begin{array}{c}\text { Output Voltage } \\
(\mathrm{Vo})\end{array}$ & $\begin{array}{c}\text { Output Current } \\
\left(\mathrm{I}_{\mathrm{o}}\right)\end{array}$ & $\begin{array}{c}\text { Output Power } \\
\left(\mathrm{P}_{\mathrm{o}}\right)\end{array}$ & $\begin{array}{c}\text { Efficiency } \\
(\%)\end{array}$ \\
\hline 1000 & 36.78 & 3.872 & 142.4 & 299.2 & 0.45 & 134.64 & 94.5 \\
800 & 33.48 & 3.524 & 118 & 299.2 & 0.37 & 110.7 \\
600 & 26.82 & 2.823 & 75.73 & 296.1 & 0.242 & 71.65 \\
400 & 18.04 & 1.899 & 34.25 & 296.1 & 0.1 & 94.81 \\
\hline
\end{tabular}

\subsection{Design and optimization of PID controller using PSO and BFA}

- Particle swarm optimization (PSO)

In different areas of application artificial intelligence has emerged as an important tool to get a global optimum solution. Different heuristic algorithms have been developed and found in literature. Particle swarm optimization (PSO) is developed by Kennedy and Eberhart by considering the behavior of swarms of bees, birds. All the limitations of genetic algorithm (GA) are overcome by this algorithm and can be applied to applications here GA can be used [25].

The main characteristic of this algorithm is robustness in solving non-linear, non-differentiability and high dimensional problems. A very less time is required to get the optimal solution of fitness function. In this algorithm the movement of particles in search space is used o reach the optimal solution. By keeping the track of particle co-ordinates the best solution $\mathrm{P}_{\text {best }}$ is obtained. The overall best solution $\mathrm{g}_{\text {best }}$ and its location obtained of the population. The velocity a each step changes to reach $P_{\text {best }}$ and $g_{\text {best }}$ [26]-[29] as shown in Figure 14. The particle is represented by $\mathrm{X}_{\mathrm{i}}=\left(\mathrm{x}_{\mathrm{i}}, \mathrm{x}_{\mathrm{i} 2}, \ldots \ldots, \mathrm{X}_{\mathrm{iD}}\right)$ in the d-dimension search space. The

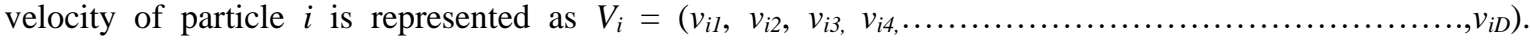
Acceleration is weighted by a random term, with separate random numbers being generated for acceleration toward $\mathrm{P}_{\text {best }}$ and $\mathrm{g}_{\text {best }}$. The position of the $i^{\text {th }}$ particle is then updated.

$$
\begin{aligned}
& \operatorname{vid}(t+1)=\omega \times \operatorname{vid}(t)+c 1 r 1(P i d-x i d(t))+c 2 r 2(\operatorname{Pgd}-x i d(t)) \\
& \operatorname{xid}(t+1)=\operatorname{xid}(t)+\operatorname{cvid}(t+1)
\end{aligned}
$$

Where, $\mathrm{P}_{\mathrm{id}}$ and $\mathrm{P}_{\mathrm{gd}}$ are $\mathrm{P}_{\text {best }}$ and $\mathrm{g}_{\text {best. }}$ It is concluded that $\mathrm{g}_{\text {best }}$ version performs best in terms of median number of iterations to converge [25]. In Figure 14 the particles $\mathrm{x}_{\mathrm{j}, \mathrm{g}}$ are the particles in search space with velocity $\mathrm{v}_{\mathrm{j}, \mathrm{g}}$ moving with momentum updated to $\mathrm{x}_{\mathrm{j}, \mathrm{g}}(\mathrm{t}+1)$ and $\mathrm{v}_{\mathrm{j}, \mathrm{g}}(\mathrm{t}+1)$ respectively to reach the local best $\mathrm{p}_{\text {best }}$ $\&$ global best $\mathrm{g}_{\text {best }}$ solution.

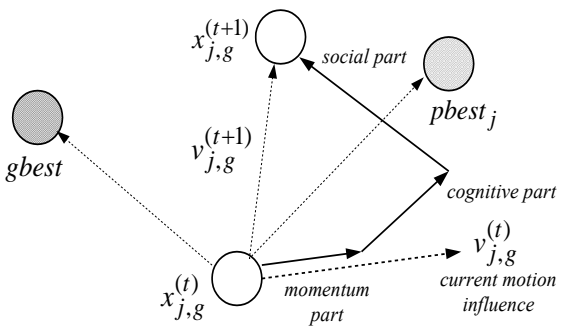

Figure 14. Description of velocity and position updates in particle swarm [25]

In complex multimodal search spaces particle swarm optimization (PSO) technique used to find the optimal solution of non-differentiable cost functions. To optimise the parameters of the PID controller to get the constant output voltage from the proposed converter coupled with the intermittent source PV, PSO is used as ouput changes with irradiance. The objective function is expressed as (12).

$$
F=\int_{0}^{t s i m}\left|\Delta v_{o}\right| \cdot t \cdot d t
$$

Where

$\Delta \mathrm{v}_{\mathrm{o}}=$ change in output voltage

tsim $=$ time period of simulation 
The PID controller is designed to reduce the settling time, maximum overshoot and the error by minimizing the objective function considered. The objective function for the problem is given as:

Minimize F,

Subject to,

$\mathrm{Kp}_{\min }<=\mathrm{Kp}<=\mathrm{Kp}_{\max }$

$\mathrm{Ki}_{\min }<=\mathrm{Ki}<=\mathrm{Ki}_{\max }$

$\mathrm{Kd}_{\min }<=\mathrm{Kd}<=\mathrm{Kd}_{\max }$

In this work PSO program has been written in the MATLAB 7.18.0.m file. The simulation model of PV module coupled with the DC-DC converter is developed in SIMULINK environment. This simulation runs for every particle in the search space to compute the objective function. The simulation results are shown in Figures 15 and 16. Figures 15 and 16 shows the output voltage waveforms of the converter, where the PID controller is optimized using PSO so that the output voltage remains constant for different values of input voltage due to different irradiance values. The results are shown in Table 3 for output voltage of the converter with changing irradiance with PID controller tuned by PSO.

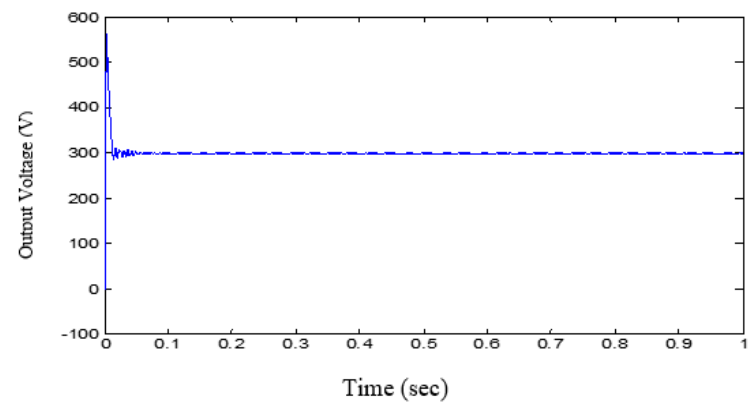

Figure 15. Output voltage of the converter is $299.9 \mathrm{~V}$ with input voltage of $36.7 \mathrm{~V}$ from PV module with irradiance $1000 \mathrm{~W} / \mathrm{m}^{2}$

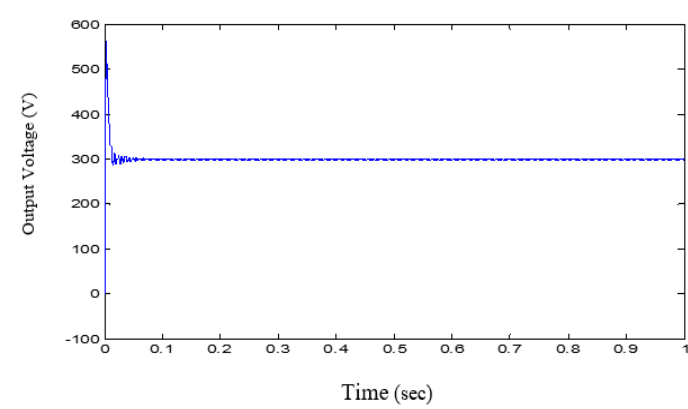

Figure 16. Output voltage of the converter is $299.9 \mathrm{~V}$ with input voltage of $26.82 \mathrm{~V}$ from PV module with irradiance $600 \mathrm{~W} / \mathrm{m}^{2}$

Table 3. Output voltage of the converter with changing irradiance with PID controller tuned by PSO

\begin{tabular}{|c|c|c|c|c|c|c|c|}
\hline $\begin{array}{l}\text { Irradiance } \\
\text { in } \mathrm{W} / \mathrm{m}^{2}\end{array}$ & $\begin{array}{l}\text { Input Voltage } \\
\left(\mathrm{V}_{\text {in }}\right) \text { in Volts }\end{array}$ & $\begin{array}{c}\text { Input Current } \\
\left(\mathrm{I}_{\text {in }}\right) \text { in } \\
\text { Ampere }\end{array}$ & $\begin{array}{l}\text { Input Power } \\
\left(\mathrm{P}_{\text {in }}\right) \text { in Watt }\end{array}$ & $\begin{array}{c}\text { Output } \\
\text { Voltage (Vo) } \\
\text { in Volts }\end{array}$ & $\begin{array}{c}\text { Output } \\
\text { Current }\left(\mathrm{I}_{\mathrm{o}}\right) \text { in } \\
\text { Ampere }\end{array}$ & $\begin{array}{l}\text { Output Power } \\
\left(\mathrm{P}_{\mathrm{o}}\right) \text { in Watt }\end{array}$ & $\begin{array}{c}\text { Efficiency } \\
(\%)\end{array}$ \\
\hline 1000 & 36.78 & 3.872 & 142.4 & 299.9 & 0.45 & 136.7 & 95.99 \\
\hline 600 & 26.82 & 2.823 & 75.73 & 299.9 & 0.242 & 72.70 & 95.99 \\
\hline 400 & 18.04 & 1.899 & 34.25 & 299.9 & 0.1 & 32.88 & 96 \\
\hline
\end{tabular}

- Bacterial foraging algorithm (BFA)

This is another optimization algorithm which uses he foraging technique of E. coli bacteria. In this algorithm four components of bacteria foraging is used, they are chemo taxis, swarming, reproduction and elimination-dispersal. Using this energy intake per unit time of E.coli bacteria is increased.

- Chemo-taxis

In this process two movements swimming and tumbling of E. coli is simulated, where $\mathrm{i}$ alternate between these movements. Suppose $\theta_{\mathrm{i}}(\mathrm{j}, \mathrm{k}, \mathrm{l})$ represents $\mathrm{i}_{\text {th }}$ bacterium at $\mathrm{j}_{\text {th }}$ chemo tactic, $\mathrm{k}_{\mathrm{th}}$ reproductive and $\mathrm{l}_{\mathrm{th}}$ elimination-dispersal step. C(i) is the size of the step taken in the random direction specified by the tumble (run length unit). Hence in this process of chemo taxis the movement of the bacterium may be represented by (3).

$$
\theta_{j}(j+1, k, l)=\theta_{i}(j, k, l)+C(i) \frac{\Delta_{i}}{\sqrt{\Delta_{t}(i) \Delta(i)}}
$$

- Swarming

In this movement groups are formed and E. coli bacteria arrange in rings and form concentric swarm patterns with high bacterial density. He communication between the cells is represented by the following function.

$$
J_{c c}\left(\theta, P(j, k, l)=\sum_{i=1}^{S} J_{c c}\left(\theta_{i}(j, k, l)\right.\right.
$$




$$
\left.J_{c c}=\sum_{i=1}^{S}\left[-d_{\text {attr }} e^{\left(-w_{\text {attractant }} \sum P_{m}=1\left(\theta_{m}-\theta_{m}^{) i}\right) 2\right.}\right]+\sum_{i=1}^{S}\left[-h_{\text {repellant }} e^{\left(-w_{\text {repellant }} \sum P_{m}=1\left(\theta_{m}-\theta_{m}^{i}\right.\right.}\right)^{2}\right]
$$

Where $J_{c c}(\theta, P(j, k, l)$ is the objective function value to be added to the actual objective function (to be minimized) to present a time varying objective function, $S$ is the total number of bacteria, $p$ is the number of variables to be optimized, which are present in each bacterium and $\theta=\left[\theta_{1}, \theta_{2}, \ldots, \theta_{p}\right.$ is a point in the $p$ dimensional search domain.

\section{- Reproduction}

In this method a healthy E. coli bacterium asexually splits into two bacteria at the location where the unhealthy bacteria die to maintain the swarm size.

- Elimination and dispersal

In this process a group of bacteria can be killed or dispersed to a new location due to change in environment.

\section{- $\quad$ Size of population 'S'}

It takes more computation time if population size is increased but optimal solution can be obtained as he concentration of will be more a particular location.

Length of chemo tactic step ' $\mathrm{C}(\mathrm{i})$ ' has to be selected carefully, if a large value is selected then local minima can be missed out else if low value then it will take more time to converge. C(i) is like a "step size" for the algorithm.

- Chemo tactic step ' $N_{c}$ '

If the size of $N c$ and number of reproduction steps ' $N_{r e}$ ' is too small, the algorithm may converge earlier. Again, the elimination and dispersal number ' $\mathrm{N}_{\mathrm{ed}}$ ' should not have a low value then random elimination-dispersal events will not be accounted for finding better nutrients. The formation of swarms depending on the availability of the nutrients affects the cell-to-cell attractant functions ' $\mathrm{J}_{\mathrm{cc}}$ '. And the selection of proper value of the elimination dispersal probability $p_{\text {ed }}$ leads to attainment of global optimum solution [30]-[31]. The BFA program has been written in the MATLAB 7.18.m file. The PV system model coupled with the DC-DC converter under study is developed in SIMULINK environment. The simulation is done for every particle in the search space for computing the objective function as shown in Figures 17 and 18. Figures 17 and 18 shows the output voltage waveforms of the converter, where the PID controller is tuned using BFA so that the output voltage remains constant for different values of input voltage due to different irradiance values. The results are shown in Table 4 for output voltage of the converter with changing irradiance with PID controller tuned by BFA.

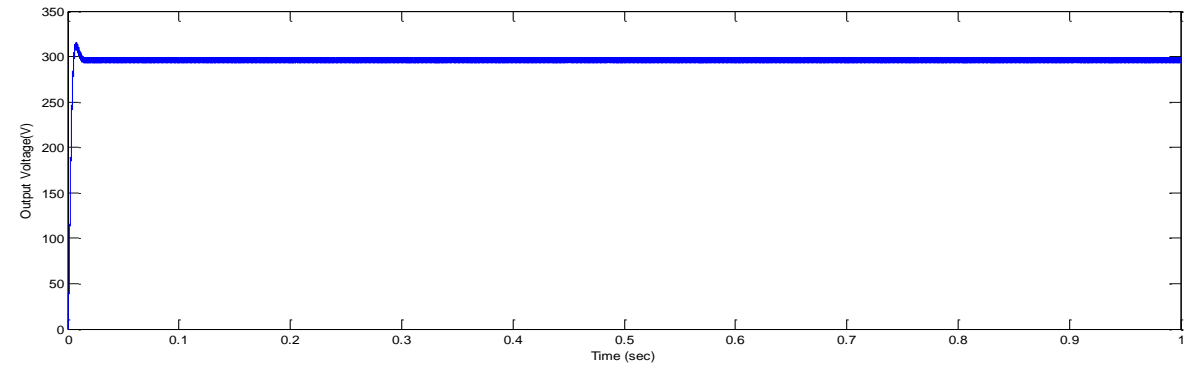

Figure 17. Output voltage of the Converter is $299.8 \mathrm{~V}$ with input voltage of $36.7 \mathrm{~V}$ from PV module with irradiance $1000 \mathrm{~W} / \mathrm{m}^{2}$

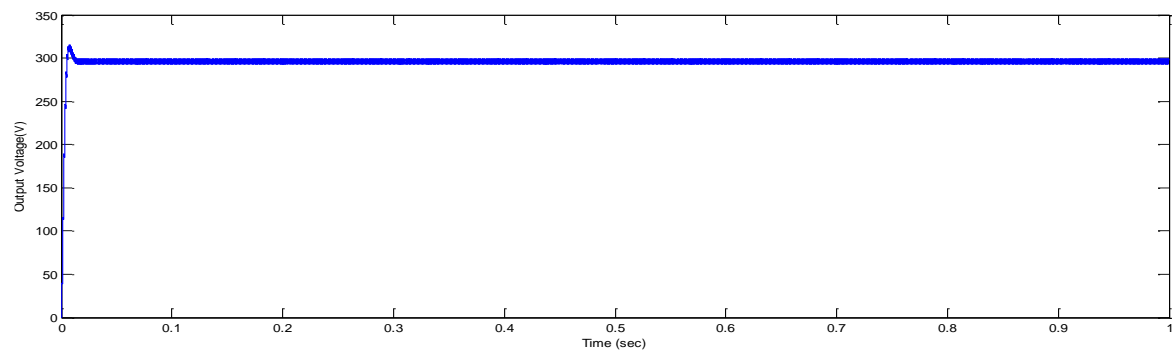

Figure 18. Output voltage of the Converter is $299.8 \mathrm{~V}$ with input voltage of $22.51 \mathrm{~V}$ from PV module with irradiance $600 \mathrm{~W} / \mathrm{m}^{2}$ 
Table 4. Output voltage of the converter with changing irradiance with PID controller tuned by BFA

\begin{tabular}{cccccccc}
\hline $\begin{array}{c}\text { Irradiance } \\
\text { in } \mathrm{W} / \mathrm{m}^{2}\end{array}$ & $\begin{array}{c}\text { Input Voltage } \\
\left(\mathrm{V}_{\text {in }}\right)\end{array}$ & $\begin{array}{c}\text { Input Current } \\
\left(\mathrm{I}_{\text {in }}\right)\end{array}$ & $\begin{array}{c}\text { Input Power } \\
\left(\mathrm{P}_{\text {in }}\right)\end{array}$ & $\begin{array}{c}\text { Output } \\
\text { Voltage }\left(\mathrm{Vo}_{0}\right)\end{array}$ & $\begin{array}{c}\text { Output } \\
\text { Current }\left(\mathrm{I}_{\mathrm{o}}\right)\end{array}$ & $\begin{array}{c}\text { Output } \\
\text { Power }\left(\mathrm{P}_{\mathrm{o}}\right)\end{array}$ & $\begin{array}{c}\text { Efficiency } \\
(\%)\end{array}$ \\
\hline 1000 & 36.78 & 3.872 & 142.4 & 299.8 & 0.45 & 134.91 \\
800 & 33.48 & 3.524 & 118 & 299.8 & 0.37 & 110.92 \\
600 & 26.82 & 2.823 & 75.73 & 299.8 & 0.242 & 72.55 \\
400 & 18.04 & 1.899 & 34.25 & 299.8 & 0.1 & 94 \\
\end{tabular}

\section{CONCLUSION}

In this work a DC-DC converter is coupled with the PV system to obtain the high output voltage. The designed high gain DC-DC converter is connected to the PV module, which gives high output voltage but it changes with the change in irradiance. In order to keep the output voltage constant at $300 \mathrm{~V}$ for different input voltages with changing irradiance a PID controller is used. At first Ziegler Nichols method is used to tune its parameters. Then the controller parameters are optimized PSO, the results shows the steady state is reached earlier than the parameters obtained by Ziegler Nichol's method. Also, the output voltage remains constant at $299.9 \mathrm{~V}$ for very low input voltage to the converter. The parameters of the PID controller are also optimized using BFA and the output voltage of the converter remains constant at $299.8 \mathrm{~V}$ for different input voltage from solar PV, also the peak overshoot is also reduced compared to PSO. A comparative analysis of these techniques, results and analysis are presented. From this work it can be concluded that this converter can be used with PV systems and a controller can be designed using the optimization techniques which will lead to an optimal control of the output as per the requirements.

\section{REFERENCES}

[1] H. Ardi, A. Ajami and M. Sabahi, "A Novel High Step-Up DC-DC Converter With Continuous Input Current Integrating Coupled Inductor for Renewable Energy Applications," IEEE Transactions on Industrial Electronics, vol. 65, no. 2, pp. 13061315, 2018, doi: 10.1109/TIE.2017.2733476.

[2] P. Wang, L. Zhou, Y. Zhang, J. Li and M. Sumner, "Input-Parallel Output-Series DC-DC Boost Converter With a Wide Input Voltage Range, For Fuel Cell Vehicles,” IEEE Transactions on Vehicular Technology, vol. 66, no. 9, pp. 7771-7781, 2017, doi: 10.1109/TVT.2017.2688324.

[3] M. Lakshmi and S. Hemamalini, "Nonisolated High Gain DC-DC Converter for DC Microgrids," IEEE Transactions on Industrial Electronics, vol. 65, no. 2, pp. 1205-1212, 2018, doi: 10.1109/TIE.2017.2733463.

[4] M. A. Salvador, T. B. Lazzarin and R. F. Coelho, "High Step-Up DC-DC Converter With Active Switched-Inductor and Passive Switched-Capacitor Networks," IEEE Transactions on Industrial Electronics, vol. 65, no. 7, pp. 5644-5654, 2018, doi: 10.1109/TIE.2017.2782239.

[5] S. Mohammadsalehian, F. Sedaghati, R. Eskandari, H. Shayeghi and E. S. Asl, “A Modified Double Input Z-source DC-DC Converter for Standalone PV/Battery System Application," 11th Power Electronics, Drive Systems, and Technologies Conference (PEDSTC), 2020, pp. 1-7, doi: 10.1109/PEDSTC49159.2020.9088453.

[6] A. H. A. Biglo, S. Farzamkia, S. Farhangi and H. I. Eini, "Utilization of Soft-Switched Boost Converter for MPPT Application in Photovoltaic Single-Phase Grid-Connected Inverter," 11th Power Electronics, Drive Systems, and Technologies Conference (PEDSTC), 2020, pp. 1-6, doi: 10.1109/PEDSTC49159.2020.9088432.

[7] D. -Y. Jung, S. -H. Hwang, Y. -H. Ji, J. -H. Lee, Y. -C. Jung and C. -Y. Won, "Soft-Switching Bidirectional DC/DC Converter with a LC Series Resonant Circuit," IEEE Transactions on Power Electronics, vol. 28, no. 4, pp. 1680-1690, 2013, doi: 10.1109/TPEL.2012.2208765

[8] T. Zhan, Y. Zhang, J. Nie, Y. Zhang and Z. Zhao, "A Novel Soft-Switching Boost Converter With Magnetically Coupled Resonant Snubber," IEEE Transactions on Power Electronics, vol. 29, no. 11, pp. 5680-5687, 2014, doi: 10.1109/TPEL.2013.2295887.

[9] W. Yu et al., "High efficiency converter with charge pump and coupled inductor for wide input photovoltaic AC module applications," IEEE Energy Conversion Congress and Exposition, 2009, pp. 3895-3900, doi: 10.1109/ECCE.2009.5316154.

[10] W. Li, Y. Zhao, Y. Deng and X. He, "Interleaved Converter With Voltage Multiplier Cell for High Step-Up and High-Efficiency Conversion," IEEE Transactions on Power Electronics, vol. 25, no. 9, pp. 2397-2408, 2010, doi: 10.1109/TPEL.2010.2048340.

[11] Y. Zhao, W. Li, Y. Deng and X. He, "Analysis, Design, and Experimentation of an Isolated ZVT Boost Converter With Coupled Inductors," IEEE Transactions on Power Electronics, vol. 26, no. 2, pp. 541-550, 2011, doi: 10.1109/TPEL.2010.2065815.

[12] K. I. Hwu and W. Z. Jiang, "Voltage Gain Enhancement for a Step-Up Converter Constructed by KY and Buck-Boost Converters," IEEE Transactions on Industrial Electronics, vol. 61, no. 4, pp. 1758-1768, 2014, doi: 10.1109/TIE.2013.2263779.

[13] E. Adib and H. Farzanehfard, "Analysis and Design of a Zero-Current Switching Forward Converter With Simple Auxiliary Circuit," IEEE Transactions on Power Electronics, vol. 27, no. 1, pp. 144-150, 2012, doi: 10.1109/TPEL.2010.2096478.

[14] Qun Zhao and F. C. Lee, "High-efficiency, high step-up DC-DC converters," IEEE Transactions on Power Electronics, vol. 18, no. 1, pp. 65-73, 2003, doi: 10.1109/TPEL.2002.807188.

[15] W. Qian, J. G. Cintrón-Rivera, F. Z. Peng and D. Cao, "A multilevel dc-dc converter with high voltage gain and reduced component rating and count," Twenty-Sixth Annual IEEE Applied Power Electronics Conference and Exposition (APEC), 2011, pp. 1146-1152, doi: 10.1109/APEC.2011.5744738.

[16] Q. Li and P. Wolfs, "A Review of the Single Phase Photovoltaic Module Integrated Converter Topologies With Three Different DC Link Configurations," IEEE Transactions on Power Electronics, vol. 23, no. 3, pp. 1320-1333, 2008, doi: 10.1109/TPEL.2008.920883

[17] J. M. K. Won, B. H. K. Won and K. H. Nam, "High-efficiency module-integrated photovoltaic power conditioning system," IET Power Electronics, vol 2, no. 4, pp. 410-420, 2009, doi: 10.1109/TPEL.2008.920883. 
[18] A. S. Nithya and G. D. A. Jebeselvi, "Design and Implementation of High Step-up DC to DC Converter with Soft Switching Method," Department of Electronics and Control Engineering, Sathyabama University, Chennai, India 2015, doi: 10.5829/idosi.mejsr.2015.23.ssps.32.

[19] K. P. Panda, P. R. Bana, P. Sanjeevikumar, G. Panda, Z. Leonowicz, and M. Mitolo; "A Single-Source High-Gain SwitchedCapacitor Multilevel Inverter with Inherent Voltage Balancing,” IEEE International Conference on Environment and Electrical Engineering 2020, doi: 10.1109/EEEIC/ICPSEurope49358.2020.9160624.

[20] M. Lopamudra, and U. K. Rout, "Performance analysis of a new high gain dc-dc converter interfaced with solar photovoltaic module," Renewable Energy Focus, vol-19-20, pp. 63-74, 2017, doi: 10.1016/j.ref.2017.05.001.

[21] L. Mitra and U. K. Rout, "Single switched inductor capacitor coupled transformerless high gain converter for PV application," IEEE 6th International Conference on Power Systems (ICPS), 2016, pp. 1-6, doi: 10.1109/ICPES.2016.7584017.

[22] A. Ahmad, R. K. Singh, and A. R. Beig, "Switched-Capacitor Based Modified Extended High Gain Switched Boost Z-Source Inverters," IEEE Access, vol. 7, pp. 179918 - 179928,2019, doi: 10.1109/ACCESS.2019.2959136.

[23] L. Mitra and N. Swain, "Closed loop control of solar powered boost converter with PID controller," IEEE International Conference on Power Electronics, Drives and Energy Systems (PEDES), 2014, pp. 1-5, doi: 10.1109/PEDES.2014.7041973.

[24] J. G. Ziegler and N. B. Nichols, "Optimum settings for automatic controllers,” Transaction of ASME, vol. 64, pp. 759-768, 1942, doi:10.1115/1.2899060.

[25] Eberhart and Yuhui Shi, "Particle swarm optimization: developments, applications and resources," Proceedings of the 2001 Congress on Evolutionary Computation (IEEE Cat. No.01TH8546), 2001, pp. 81-86 vol. 1, doi: 10.1109/CEC.2001.934374.

[26] J. Zhao, T. Li and J. Qian, "Application of particle swarm optimization algorithm on robust PID controller tuning," Advances in Natural Computation - Springer, vol. 3612, pp. 948-957, 2005, doi: 10.1007/11539902_118.

[27] J. Danijel B. ,Ozren and G. Frano, "GA Optimized AVR Controller with Higher Degree of Freedom of Tuning of Wanted Response," International Review of Automatic Control, vol. 8, no. 1, pp. 1689-1698, 2015, doi: https://doi.org/10.15866/ireaco.v8i1.5244.

[28] J. Dash, B. Dam and R. Swain, "Optimal design of linear phase multi-band stop filters using improved cuckoo search particle swarm optimization," Applied Soft Computing, vol. 52, pp. 435-445, 2017. doi: 10.1016/j.asoc.2016.10.024.

[29] J. Dash, B. Dam, and R. Swain, "Design of multipurpose digital FIR double-band filter using hybrid firefly differential evolution algorithm," Applied Soft Computing, pp. 529-545, 2017, doi: 10.1016/j.asoc.2017.06.025.

[30] C Liu, J Wang and J. Y. T "LeungWorker assignment and production planning with learning and forgetting in manufacturing cells by hybrid bacteria foraging algorithm," Computers \& Industrial Engineering, pp. 162-179, 2016,doi: 10.1016/j.cie.2016.03.020.

[31] D. Wang, X. Qian, X. Ban, B. Ma, Y. Ma and Z. Lv, "Enhanced Bacterial Foraging Optimization Based on Progressive Exploitation Toward Local Optimum and Adaptive Raid," IEEE Access, vol. 7, pp. 95725-95738, 2019, doi: 10.1109/ACCESS.2019.2927327.

\section{BIOGRAPHIES OF AUTHORS}

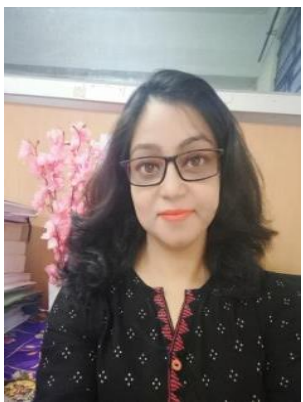

Lopamudra Mitra (D) SI SC P currently working as Sr. Assistant Professor in the Department of Electrical Engineering, Silicon Institute of Technology, Bhubaneswar. She received her B.Tech in Electrical and Electronics Engineering from National Institute of Science and Technology and M.Tech with specialization in Power Electronics and Drives from KIIT University, Bhubaneswar. She had completed her PhD from KIIT University, Bhubaneswar. Presently carrying her research in the area of Power Electronics and Renewable Energy Systems. She can be contacted at email: lopamudra.mitra2015@gmail.com.

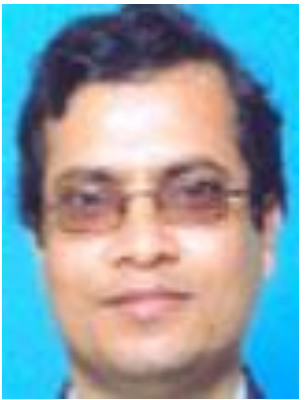

Ullash Kumar Rout (iD BI SC P is currently working as Associate Professor in the department of Electrical Engineering, CET, Bhubaneswar. He received his B. Tech. in Electrical Engineering from Utkal University, M. Tech. in Power System from IIT Kanpur, and Ph.D. in Energy System from University of Stuttgart, Germany. He has around 15 years of research experience in energy system modelling and 15 years in teaching. His research interest includes energy system and power system. He can be contacted at email: ullashrout@rediffmail.com. 